\title{
Analysis and interpretation of inorganic mineral particles in "lung" tissues
}

\author{
Allen R Gibbs, Frederick D Pooley
}

In his foreword to H Spencer's Pathology of the Lung Dr Liebow wrote: “A man's medical history and the traces of his habits and his trade are often inscribed upon the lungs - for him who can read." This is particularly pertinent to the mineral content of the lung and its associated pathology. If we had sufficiently sophisticated methods of analysis we would be able to determine his life's journeys, occupations, and customs. In part we can do this, since for many occupational lung diseases it is the retained mineral particles that are important in pathogenesis. Mineral analysis of the lung tissues for certain types of particle will give a more accurate reflection of the exposure than the occupational history. It is not difficult to see why. The mineral exposures relevant to a particular pathology are usually sustained several decades before the clinical manifestations of the disease - for example, the latency of asbestos related mesothelioma averages $30-40$ years. The important exposures are to the airborne particles with aerodynamic diameters of less than $5 \mu \mathrm{m}$ and the relevant particles may be a small proportion of a much greater mixture of particles. An individual will make a very poor assessment of this and it is only in recent years that airborne sampling has provided detailed counts of the relevant particles.

Studies of airborne dust and particle retention in the lungs have been conducted since the beginning of this century using the optical microscope. ${ }^{2-4}$ These techniques were severely limited, however, because many of the important particles were below the optical resolution of the microscopes and also many minerals cannot be distinguished by optical properties alone. Chemical methods were also used to study the composition of dust extracted from tissues digested by strong alkalis and/or acids, but most gave only elemental values information which is inadequate for mineral identification. In the 1950 s the availability of $x$ ray diffractometers and the development of quantitative techniques resulted in a number of publications pertaining to quartz in lung dust extracts, particularly from coal workers. ${ }^{5-8}$ However, it should be kept in mind that there were considerable technical difficulties related to preparation and extraction of the dust from the tissues and mineralogical characterisation with all these early studies. ${ }^{9}$ A further limitation
Table 1 Factors to be considered before undertaking mineral analysis

Effects of sampling

Tissue available

Tissue preparation

What components of the dust need to be identified and quantified?

What physical parameters need to be evaluated?

Can the sample under investigation be compared with adequate control specimens?

for wet chemical and $x$ ray diffraction techniques is that they require a large quantity of dust for analysis, sometimes necessitating the use of a whole lung.

In the past two decades the great improvement in analytical equipment and the use of electron microscopy has enabled a much more accurate and meaningful analysis of the inorganic mineral content of the lung. The use of multiple techniques has provided useful information on non-fibrous silicate pneumoconioses, ${ }^{1011}$ silicosis, ${ }^{12}$ and asbestos-related lung disorders. ${ }^{13-18}$

Before one embarks on the mineral analysis of lung tissue to assess the role of a particular mineral(s) in a pathological reaction, there are a number of factors to take into consideration (table 1).

\section{Sampling and tissue availability}

Sampling will depend to a certain extent on the tissue samples available. The ideal is to have a lung or sagittal slice of lung from which multiple samples can be taken. In our laboratory we take samples from the apical upper, apical lower, and basal segments of the lung. These samples are combined and the analysis carried out on the pooled sample. The tissue collected for analysis (and assessment of fibrosis) should not contain tumour since mineral particles are scarce in tumours and analysis of tumorous tissue will result in a false low count. Several investigators have shown that there is variation of results from the same lung when multiple separate small samples are analysed because there is an uneven distribution of fibres within the lung, ${ }^{19-22}$ just as examination of lungs for fibrosis shows variation from area to area. Churg and Wood $^{22}$ examined multiple $1 \mathrm{ml}$ samples of lung from each of nine subjects and found a mean in case ratio of maximum to minimum fibre concentration of $7 \cdot 5$ for amosite and Minerals, Cardiff

School of Engineering University of Wales, F D Pooley

Correspondence to: Dr A R Gibbs. 
and crocidolite, $7 \cdot 0$ for tremolite, 3.8 for chrysotile, and 4.0 for non-asbestos fibres. They recommended that larger or several pieces of lung tissue should be analysed. We have found that if multiple pieces are pooled and examined there is much less variation - an average of $50 \%$ and a maximum of three fold. Some investigators have suggested that fibre levels are much higher in subpleural than central regions of the lung, but in a study of asbestosrelated diffuse pleural fibrosis we found no significant difference in fibre levels between the central and subpleural zones although the levels were much lower in the pleura. ${ }^{13}$ Churg et al ${ }^{14}$ found no difference between peripheral and central lung parenchyma in Canadian chrysotile workers. Analysis can be performed on large biopsies (open or thoracoscopic) and, if wet tissue is not available, on tissue retrieved from paraffin wax blocks. Endoscopic biopsy specimens are not suitable because of the paucity of tissue which comes immediately from around large airways.

Analyses have also been carried out on sputum and bronchial lavage samples but these investigations have been few with limited information about correlations with lung tissue content.

\section{Tissue preparation}

The preparation of the tissues is critical in obtaining an accurate result. The aim is to remove the biological material efficiently from the specimen in order to leave the dust as little altered as possible. A variety of chemical digestive techniques have been used utilising acids, alkalis, enzymes, formamide, or sodium hypochlorite. ${ }^{23-29}$ As an alternative, ashing techniques have been used but these have many drawbacks - they tend to produce "dirtier" preparations than chemical digestion and, if prolonged, which is necessary to produce clean backgrounds if they are used on their own, they can cause pronounced physical alterations of the fibres. The procedure used depends to a certain extent on the minerals that are of interest. For routine analysis of mineral fibres we have found that a combination of potassium hydroxide digestion followed by a brief period of low temperature plasma ashing is the optimum method ${ }^{9}$ which gives a clean background for counting and good preservation of the mineral particles.

Care has to be taken during the sampling and preparation procedures to avoid contamination with inorganic particles from the workplace environment or other specimens. Recently Lee and Florida ${ }^{30}$ drew attention to the possible contamination of paraffin wax blocks by asbestos fibres. However, in general the contamination, when it occurs, is so low that it should not significantly affect the results and the inclusion of appropriate blanks and controls should obviate the problems. ${ }^{31}$

\section{Quantitation}

\section{FIBROUS MINERAIS}

There are relatively inexpensive simple methods for counting fibres and/or ferruginous bodies of lung digests by light microscopical methods. ${ }^{32} \mathrm{~A}$ common mistake is to state that these are asbestos fibres and bodies, whereas the techniques are unable to give a precise characterisation of the types of fibre present. In many situations - for example, in insulation workers known to have been heavily exposed to asbestos several decades before - it is reasonable to assume that the fibres and ferruginous bodies are asbestos. However, in some cases, particularly where there are mixed exposures to minerals - for example, in foundry workers - many of the fibres and bodies may not be asbestos. An investigation by transmission electron microscopy of bronchoalveolar lavage samples from five foundry workers showed that some of the transparent cored ferruginous bodies diagnosed as asbestos bodies by light microscopy were not composed of asbestos but of fibre glass, sheet silicates, and carbon. ${ }^{33}$ A number of minerals which can form ferruginous bodies may be mistaken for asbestos including carbon, iron oxide, rutile, aluminium oxide, chromium oxide, mullite, kaolin, mica, talc, glass, and erionite. ${ }^{3435}$ These differ in appearance from asbestos bodies by having broad yellow or black cores. However, when there are several types present it will be difficult to obtain an accurate impression of how many are true asbestos bodies by light microscopy alone. Electron microscopic analytical techniques are required to identify these and should also be used when there is doubt about the occupational history. Those procedures which count only "asbestos" bodies have very limited usefulness since it is the number of uncoated fibres present which is important in the pathogenesis of disease. There is considerable variation in the ratio of uncoated to coated fibres which depends on the type of fibre and numbers present. A comparative study of light to electron microscopic counts has shown a disproportionately high ratio of coated to uncoated fibres when fibre counts are low, ${ }^{36}$ so one cannot easily extrapolate from counts of asbestos bodies to numbers of uncoated fibres.

Investigators have used a number of different methods for counting fibres, some have preferred to use the scanning electron microscope and others the transmission electron microscope. Providing the microscopes are fitted with an energy dispersive $x$ ray spectrometer, the chemistries of the fibres can be obtained and thus identified. The transmission electron microscope has a number of advantages: (1) it can be operated at high magnifications which resolves fine particles. Low magnifications of less than $\times 5000$ will not detect fibres thinner than $0.2 \mu \mathrm{m}$ and, since a large proportion of crocidolite and chrysotile fibres are below this, they may not be detected in cases where there are significantly increased amounts of these fibres; (2) a fibre can be analysed at multiple points along its length which gives an assessment of homogeneity; and (3) selected area diffraction can be performed at various points on the fibre providing crystallographic information about the mineral which, combined with the chemical information obtained from 
the energy dispersive $x$ ray spectometer, will give a precise identification. ${ }^{29}$

There has also been variation in the counting and expression of results. Some investigators only count fibres of more than a certain length whereas others count all. It is our practice to count and type 100-200 fibres of all sizes per investigation. Investigators should not rely on the results obtained by typing tens of fibres which can be unrepresentative. Although there is evidence to suggest that it is the long fibres of $>5 \mu \mathrm{m}$ in length which are the most important in causing asbestos-related disease, it is not conclusive and the shorter fibres may also play some part. ${ }^{37}$ It is also useful to have this information to compare with other mineral particle associated diseases. It could be argued that the number of fibres of $<5 \mu \mathrm{m},>5 \mu \mathrm{m}$, and $>8 \mu \mathrm{m}$ in length should be separately recorded. The counts of fibres of more than $5 \mu \mathrm{m}$ in length would compare more easily with regulatory fibres.

The number of asbestos bodies, uncoated fibres, or total fibres may be related to a mass of wet or dried lung (usually per g), or volume of lung (usually per $\mathrm{ml}$ ). We believe that the most appropriate way to express the results is per $g$ of dried lung tissue. The mass of wet lung will depend on the amount of congestion and oedema and the volume will depend on the degree of insufflation by the laboratory which are highly variable factors. Some investigators do not measure the wet to dry weight for each sample but multiply the result per wet weight of tissue by a factor of 10 to get the number per dry weight. This can result in considerable inaccuracies. The wet to dry ratio can vary from 6 to 14 and therefore it is best to determine the wet to dry ratio for each case.

We also prefer to give the total number of the relevant fibres rather than bodies. Counts of asbestos bodies do not show a consistent relationship to fibres since ferruginous body formation varies according to a number of factors including fibre type, length, the number, and the quantity of iron within the lung. For example, a higher proportion of a given number of amosite fibres will form asbestos bodies than the equivalent number of crocidolite fibres while a very small proportion $(0 \cdot 14 \%$ on average) of chrysotile fibres form asbestos bodies. ${ }^{36}$ Churg and colleagues have analysed 600 asbestos bodies from 82 subjects who were not asbestos workers and found that $98 \%$ had an amphibole core and $2 \%$ a chrysotile asbestos core. ${ }^{38}$ It has therefore been assumed that ferruginous bodies with a thin transparent fibrous core are nearly always asbestos. This was probably true until recently but we are now seeing similar bodies which have non-asbestos cores on analysis. The situation may therefore be changing with the decreased use of asbestos and the increasing use of substitute materials. Table 2 lists some of the problems of asbestosrelated disease where mineral analysis may be helpful.

It is often forgotten that fibres other than asbestos are present in lung tissues from nonindustrially and industrially exposed individuals including mullite, kaolin, mica, talc,
Table 2 Indications for mineral analysis

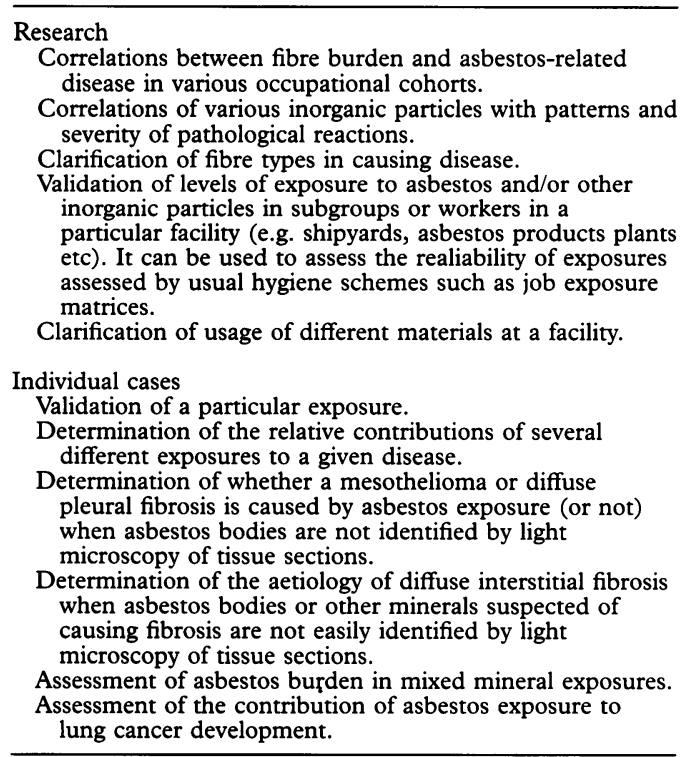

silica, and rutile. Often non-asbestos fibres account for the greater proportion of the fibres. There has been little research on the effects of these fibres on the lung, either alone or in combination with asbestos fibres.

\section{NON-FIBROUS MINERALS}

Detection, counting, and identification of fibrous dust particles in biological specimens has in the past 15 years represented the majority of investigations concerning minerals in the lungs. This is understandable considering the hysterical publicity given to information dealing with exposure to asbestos dust and its associated diseases, but it is also related to the fact that asbestos fibres are the easiest of the inorganic mineral particles to detect, count, and identify within the lungs. Numerous publications have been used for reference to the asbestos content of lung tissues but many of these have been flawed by the ill considered choice of analytical techniques used in the performance of their investigations.

In general, non-fibrous particles have few morphological features which can be used to distinguish them with any certainty. In situations where exposures to specific dusts or fumes have been recorded, particles may be identified by their shape. Minerals such as talc, the micas, kaolin, and other clays can be identified by their plate-like translucent appearance. Kaolin particles can often be distinguished by their hexagonal particle shape, but this is not a feature of all samples. Fume particles also have a distinctive appearance, being characterised by very small round particles occurring as aggregates, often with a chainlike appearance (fig 1). These physical features cannot normally be recognised by light microscopic techniques but are readily visible with either transmission or scanning electron microscopy.

Quantification of non-fibrous particles in lung tissue on a particle number basis using their morphology is not of any scientific use. Morphological differences do not identify part- 

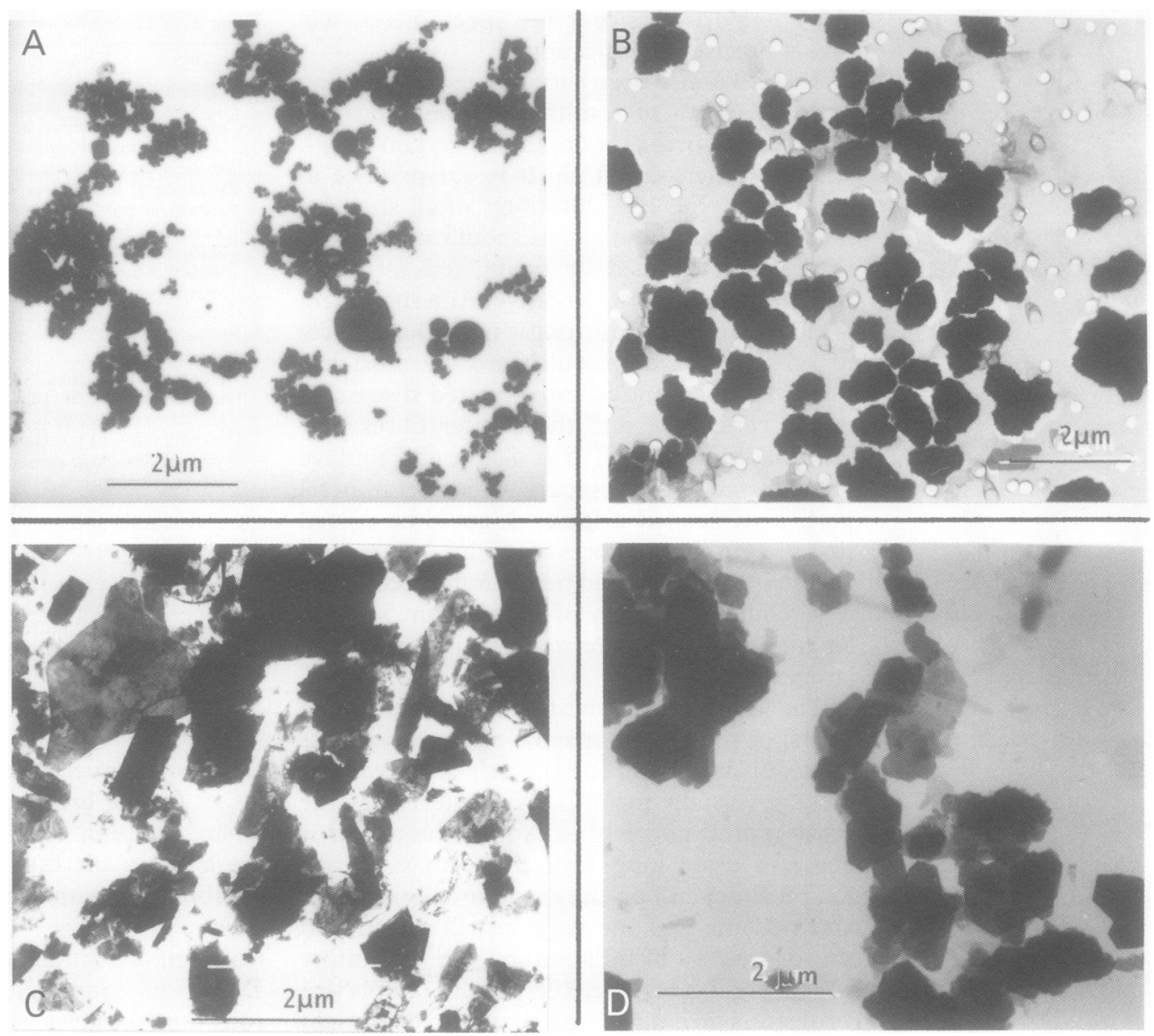

Figure 1 Electron micrographs of non-fibrous dust particles illustrating morphological difference: (A) metal oxide fume; (B) zeolite particles; (C) flaky talc particles; (D) kaolin particles.

icles accurately enough to allow particle counts to be used as a mass estimate of material. Quantification on a particle number basis is confined historically to asbestos fibre because dust particles with dimensions similar to the commercial asbestos minerals are extremely rare. It is still necessary in the case of asbestos fibres to analyse them individually to establish their identity so that accurate estimates of individual asbestos minerals can be obtained.

Non-fibrous dusts and fume particles are normally quantified by analytical techniques which are capable of estimating their mass concentration in lung tissue. The mass concentration of the total dust in the tissue must be determined as accurately as possible before attempting its analysis; this is best done gravimetrically using multiple preparations of tissue. Dust extracts are then examined to determine the identity and proportions of the components that they contain. This result is most conveniently obtained with an analytical transmission electron microscope which can be used to examine individual particles and provide a rough estimate of their concentration and a more accurate determination of their identity by their chemistry and sometimes their electron diffraction patterns. The chemistry of individual particles may not be enough to identify them and samples may have to be subjected to other forms of analysis to confirm their identity and establish their mass concentrations.
$X$ ray diffraction examination of samples can provide some of this information since it can be used to identify crystalline components and, by calibration with suitable standards, it can be employed to measure the mass concentration of individual crystalline components. It is not suitable for the identification and quantification of non-crystalline components. The quantity of these phases can only be established by careful measurement of the chemical composition of individual dust components.

The analytical transmission electron microscope is the only way to obtain an analysis of individual components and it can provide a bulk chemical analysis. More accurate estimations of the dust chemistry can be made using spectroscopic techniques of which the most useful is inductively coupled plasma atomic emission spectroscopy (ICP-AES). With this technique suspensions of dust can be directly aspirated into the equipment to read routinely more than 70 major and minor elements. There is no requirement to dissolve the particles, obviating problems associated with sample preparation. These elements can be proportioned to reveal the composition of the individual components of dust extracts. The sensitivity for a large number of elements with this technique is generally in the $\mu \mathrm{g} / \mathrm{l}$ (ppb) range. Considerable accuracy can be achieved with this technique for the multi-element analysis of dusts extracted from lung tissues. 


\begin{tabular}{lllllllll}
\hline \multicolumn{1}{l}{ Oxide mass percentages } \\
\cline { 2 - 9 } & $\mathrm{SiO}_{2}$ & $\mathrm{Na}_{2} \mathrm{O}$ & $\mathrm{MgO}$ & $\mathrm{Al}_{2} \mathrm{O}_{3}$ & $\mathrm{~K}_{2} \mathrm{O}$ & $\mathrm{TiO}_{2}$ & $\mathrm{MnO}$ & $\mathrm{FeO}$ \\
\hline Bulk analysis & $51 \cdot 3$ & $0 \cdot 4$ & $1 \cdot 3$ & $31 \cdot 2$ & $6 \cdot 1$ & $2 \cdot 8$ & $0 \cdot 2$ & $6 \cdot 8$ \\
Individual mineral phase & & & & & & & & \\
$(1)$ & $50 \cdot 3$ & $0 \cdot 1$ & $1 \cdot 7$ & $33 \cdot 7$ & $9 \cdot 4$ & $\mathrm{ND}$ & $0 \cdot 2$ & $4 \cdot 2$ \\
$(2)$ & $51 \cdot 8$ & $2 \cdot 4$ & $1 \cdot 7$ & $38 \cdot 8$ & $1 \cdot 8$ & $\mathrm{ND}$ & $0 \cdot 2$ & $3 \cdot 4$ \\
$(3)$ & $38 \cdot 3$ & $0 \cdot 1$ & $10 \cdot 3$ & $36 \cdot 6$ & $0 \cdot 6$ & $\mathrm{ND}$ & $0 \cdot 1$ & $13 \cdot 6$ \\
$(4)$ & $52 \cdot 6$ & $\mathrm{ND}$ & $0 \cdot 6$ & $43 \cdot 8$ & $0 \cdot 2$ & $\mathrm{ND}$ & $0 \cdot 2$ & $2 \cdot 3$ \\
$(5)$ & $98 \cdot 7$ & $0 \cdot 01$ & $\mathrm{ND}$ & $0 \cdot 7$ & $0 \cdot 2$ & $\mathrm{ND}$ & $0 \cdot 2$ & $0 \cdot 2$ \\
$(6)$ & $\mathrm{ND}$ & $\mathrm{ND}$ & $\mathrm{ND}$ & $\mathrm{ND}$ & $\mathrm{ND}$ & $\mathrm{ND}$ & $\mathrm{ND}$ & $100 \cdot 0$ \\
$(7)$ & $\mathrm{ND}$ & $\mathrm{ND}$ & $\mathrm{ND}$ & $\mathrm{ND}$ & $100 \cdot 0$ & $\mathrm{ND}$ & $\mathrm{ND}$ & $\mathrm{ND}$ \\
$(8)$ & $\mathrm{ND}$ & $\mathrm{ND}$ & $\mathrm{ND}$ & $100 \cdot 0$ & $\mathrm{ND}$ & $\mathrm{ND}$ & $\mathrm{ND}$ & $\mathrm{ND}$ \\
\hline
\end{tabular}

Contribution of each mineral phase to the bulk: phase 1 (muscovite/illite) $55.4 \%$; phase 2 (sodium muscovite) $4 \cdot 1 \%$; phase 3 (chlorite) $3.3 \%$; phase 4 (kaolin) $26.4 \%$; phase 5 (quartz) $6.6 \%$; phase $6(\mathrm{FeO}) 1.7 \%$; phase $7\left(\mathrm{TiO}_{2}\right) 0.8 \%$; phase $8\left(\mathrm{Al}_{2} \mathrm{O}_{3}\right) 1.7 \%$.

\begin{tabular}{lllllllll}
\hline & $\mathrm{SiO}_{2}$ & $\mathrm{Na}_{2} \mathrm{O}$ & $\mathrm{MgO}$ & $\mathrm{Al}_{2} \mathrm{O}_{3}$ & $\mathrm{~K}_{2} \mathrm{O}$ & $\mathrm{TiO}_{2}$ & $\mathrm{MnO}$ & $\mathrm{FeO}$ \\
\hline $\begin{array}{l}\text { Chemistry of dust calculated } \\
\text { from individual mineral } \\
\text { proportions }\end{array}$ & 51.3 & 0.4 & 1.3 & 31.2 & 6.1 & 2.8 & 0.2 & 6.7 \\
\hline
\end{tabular}

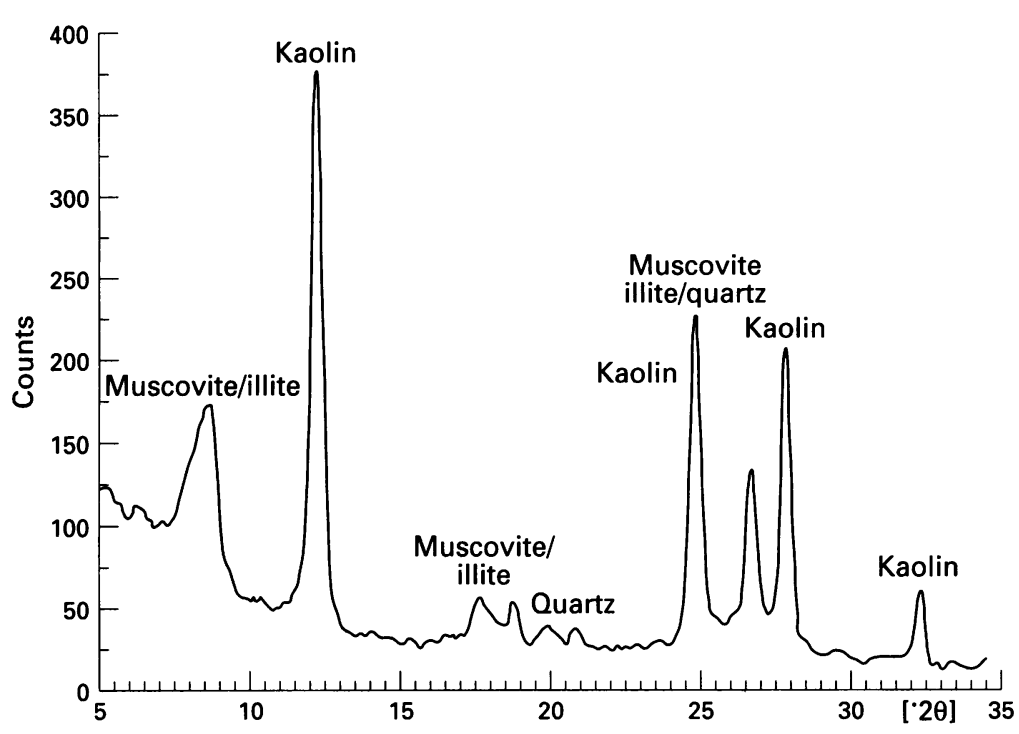

Mineral phase composition obtained from $x$ ray diffractometry:

Kaolin: $28 \cdot 7 \%$

Quartz: $6 \cdot 8 \%$

Figure 2 Example of the analysis of the inorganic fraction of the dust found in a coal miner's lung by transmission electron microscopy and $x$ ray diffractometry.

An example of the manner in which data obtained by analytical electron microscopy, $x$ ray diffractometry, and ICP-AES can be combined to produce an overall analysis of dust extract is given in fig 2 . It shows the complex nature of the retained mineral content in the lung of a coal worker which can only be characterised by the use of multiple techniques.

These procedures have been relatively underused but they can and have provided useful information in slate workers' pneumoconiosis, china clay workers' pneumoconiosis, talc pneumoconiosis, and exposures to metals.

\section{Interpretation}

Correct interpretation of results from a single case or series of cases requires comparison with values obtained from series of controls performed with the same techniques and procedures. In practice this means controls examined by the same laboratory. Ideal studies would include epidemiological and hygiene estimates of exposure, systematic sampling of lung tissues for both histopathological and mineralogical evaluation, and, where possible, controls should include subjects with no known exposure and subjects with exposure to the mineral of interest but without related disease. In this way necroscopic and case referral bias will be reduced although not completely eliminated.

Unfortunately there are no studies which have compared well characterised airborne fibrous or non-fibrous particle measurements with the mineral particle burden of the lung. Deposition of particles is critically dependent on shape and size distribution and this historical exposure information is lacking. The mineral particle burden of the lung is a reflection of this, provided the fibres are durable in lung tissues, but it does not indicate the number cleared and cannot, for example, provide any reliable information concerning past exposure to chrysotile. ${ }^{39}$ Nevertheless, although there are limitations to the interpretation, the mineral particle analysis of lung tissue can provide extremely useful information with regard to assessment of severity and type of exposures.

Knowledge of dose responses is also necessary. There is a common misconception that the presence of asbestos in the lungs of a subject with a lung cancer implies that it had a role in the causation of the tumour, whereas the main body of evidence indicates that the risk of lung cancer only increases in those with substantial exposure. For example, a level of 2 million fibres of crocidolite per $\mathrm{g}$ of dry lung tissue in our laboratory would be regarded as causative of a mesothelioma but not a lung cancer. We have found that severe clinical asbestosis (with symptoms and radiological changes) is usually associated with combined amphibole levels of more than 1000 million fibres per $g$ dry lung tissue.

\section{Asbestos-related diseases} ANALYSIS OF LUNG TISSUES

It should be realised that the lungs of everyone in the population contain some asbestos fibres and bodies ${ }^{40}$ which have come from both environmental and industrial sources. It is interesting to note that chrysotile fibres have been found in ten thousand year old ice samples from Antarctica. ${ }^{41}$ Mineral analysis of lung tissues has provided a considerable amount of useful information in clarifying the roles of the various fibre types and assessing dose responses (table 3 ). It has shown a gradient for various asbestos-related diseases: highest in asbestosis and lung cancer, lower for mesothelioma and diffuse pleural fibrosis, and lowest for pleural plaques. ${ }^{4042-47}$ Non-exposed controls uncommonly show combined amphibole levels of more than two million fibres per $\mathrm{g}$ whereas most cases of mesothelioma and asbestosrelated diffuse pleural fibrosis exceed this but frequently do not reach the levels associated wth asbestosis which, for the earliest microscopic grade, exceeds 50 million amphibole fibres/g. Studies have shown a correlation between amphibole asbestos fibre burden and (a) extent of occupational exposure to asbestos, ${ }^{44}$ 
Table 3 Mean (range) concentrations of mineral fibres in various asbestos associated diseases (millions of fibres/g dry lung)

\begin{tabular}{|c|c|c|c|c|}
\hline Disease (n) & Reference & Chrysotile & Amosite & Crocidolite \\
\hline Controls (55) & 13 & $\stackrel{2 \cdot 8}{(N D-11 \cdot 7)}$ & $\begin{array}{c}0.09 \\
(\mathrm{ND}-1 \cdot 0)\end{array}$ & $\begin{array}{c}0.14 \\
(\mathrm{ND}-1 \cdot 7)\end{array}$ \\
\hline$(56)$ & 16 & $9 \cdot 27$ & 0.93 & 1.00 \\
\hline$(31)^{*}$ & 59 & $\begin{array}{l}4 \cdot 4 \\
(\mathrm{ND}-20 \cdot 1)\end{array}$ & $\begin{array}{c}0.02 \\
(\mathrm{ND}-0.5)\end{array}$ & $\begin{array}{c}0.02 \\
(\mathrm{ND}-0.5)\end{array}$ \\
\hline (56) & 17 & $\begin{array}{c}7 \cdot 0 \\
\text { ND-50.4) }\end{array}$ & $\begin{array}{c}0.2 \\
(\mathrm{ND}-1.5)\end{array}$ & $\begin{array}{c}0.4 \\
(\mathrm{ND}-1 \cdot 7)\end{array}$ \\
\hline $\begin{array}{l}\text { Pleural } \\
\text { mesotheliomas (9) }\end{array}$ & 16 & $44 \cdot 69$ & 103.3 & $53 \cdot 11$ \\
\hline $\begin{array}{l}\text { Peritoneal } \\
\text { mesotheliomas (10) }\end{array}$ & 16 & $75 \cdot 24$ & $100 \cdot 6$ & $304 \cdot 91$ \\
\hline Mesotheliomas (117)* & 59 & $\begin{array}{l}7 \cdot 1 \\
(\text { ND-2506) }\end{array}$ & $\begin{array}{c}0.09 \\
\text { (ND-2420) }\end{array}$ & $\begin{array}{c}5 \cdot 1 \\
(\mathrm{ND}-2888)\end{array}$ \\
\hline Mesotheliomas (5) & 18 & $\begin{array}{c}9 \cdot 72 \\
(\mathrm{ND}-23.9)\end{array}$ & $\begin{array}{l}1000 \cdot 7 \\
(2 \cdot 4-2083)\end{array}$ & $\begin{array}{c}17 \cdot 44 \\
\text { ND-86.3) }\end{array}$ \\
\hline $\begin{array}{l}\text { Diffuse pleural } \\
\text { fibrosis }(13) \dagger\end{array}$ & 13 & $\begin{array}{l}8.65 \\
(0 \cdot 2-523)\end{array}$ & $\begin{array}{c}2 \cdot 05 \\
(0 \cdot 1-1957)\end{array}$ & $\begin{array}{c}2 \cdot 75 \\
(\mathrm{ND}-305)\end{array}$ \\
\hline $\begin{array}{l}\text { Pleural } \\
\text { plaques }(22) \dagger\end{array}$ & 60 & $\begin{array}{c}0 \cdot 3 \\
(\mathrm{ND}-2 \cdot 7)\end{array}$ & $\begin{array}{c}0.4 \\
(N D-11 \cdot 2)\end{array}$ & ND \\
\hline $\begin{array}{l}\text { Severe } \\
\text { asbestosis (9) }\end{array}$ & 16 & $69 \cdot 42$ & $447 \cdot 8$ & $1084 \cdot 7$ \\
\hline $\begin{array}{l}(11) \\
(16)\end{array}$ & $\begin{array}{l}18 \\
41\end{array}$ & $\begin{array}{r}19 \cdot 2 \\
178 \cdot 5\end{array}$ & $\begin{array}{r}1416 \cdot 3 \\
841 \cdot 6\end{array}$ & $\overline{1326} \cdot 2$ \\
\hline
\end{tabular}

* Geometric mean.

† Median.

$\mathrm{ND}=$ not detected.

The controls were subjects without asbestos-related disease and not known to have been exposed.

(b) severity of lung fibrosis, ${ }^{18374244}$ and (c) relative risk of mesothelioma. Mineral analysis has also been useful in clarifying the use of various types of asbestos in particular factories. It was thought, for example, that the workers at a textile plant in Rochdale were exposed to chrysotile with little or no amphibole asbestos and yet there had been an increased rate of lung cancer and mesotheliomas in the work force. Mineral analysis of the lung tissues from the workers revealed a considerable amount of crocidolite asbestos ${ }^{48}$ and it subsequently transpired with further investigations that significant usage of crocidolite asbestos had in fact taken place. Mineral analysis can be useful in assessing the role of asbestos in causing mesothelioma in those subjects with a negative or questionable exposure. ${ }^{47}$ In most of these cases asbestos bodies will not be identified in histological sections of the lungs. Table 2 gives indications where mineral analysis might be useful.

Analysis of the non-asbestos fibres, which we perform routinely, can provide important information. For example, we recently encountered a case of lung cancer where the role of exposure to asbestos was questioned. Asbestos fibre levels were not significantly raised but nickel fibres were found which led us to perform an analysis of the non-fibrous particles - this demonstrated large numbers of nickel and nickel alloy particles. It transpired that the individual had had substantial exposure to various nickel species during his employment.

ANALYSIS OF LAVAGE SPECIMENS

Analyses of bronchoalveolar lavage specimens has only been carried out relatively recently and there is a limited amount of information. We have encountered a number of different non-fibrous and fibrous particles in lavage specimens from non-industrially exposed subjects including silica, talc, mica, kaolin, iron, aluminium, chlorite, titanium, mullite, and chrysotile.

There have been few studies which have compared the results of analyses of bronchoalveolar fluid and tissue in the same individuals. ${ }^{48-50}$ De Vuyst et $a l^{49}$ found a good correlation between asbestos body counts in lavage fluid and lung tissues - a count of $<1$ asbestos body per $\mathrm{ml}$ of lavage fluid was associated in $70 \%$ with a lung tissue count of $<1000$ asbestos bodies per $\mathrm{g}$ dry lung; a count of 1-5 asbestos bodies per $\mathrm{ml}$ of lavage fluid was associated in $84.3 \%$ with a count of $>1000$ asbestos bodies per g dry lung; and a count of $>10$ asbestos bodies per $\mathrm{ml}$ of lavage fluid was associated in all with a count of $>10000$ asbestos bodies per $g$ dry lung. Most investigators have agreed that levels of $>1$ asbestos body per $\mathrm{ml}$ by light microscopy signifies significant exposure to asbestos. ${ }^{4-50}$ Techler et $a l^{48}$ in a similar comparison found that asbestos bodies in lung tissue were considerably longer than in lavage fluid $(8 \cdot 2$ versus $4.8 \mu \mathrm{m})$ but they were of similar width. However, the absence of amphibole fibres in bronchoalveolar lavage fluid cannot completely exclude significant retention of amphibole fibres within the lung. For example, analysis of a bronchoalveolar lavage sample from a subject with mesothelioma who had been a ceiling tile fitter up until the onset of his illness demonstrated calcium silicate and chrysotile fibres. He died approximately seven months later and analysis of necroscopic tissues revealed chrysotile and a significantly raised amosite level. Interestingly, the calcium silicate fibres were not detected, indicating that they were of short durability in lung tissues.

\section{Silicate pneumoconioses}

Silicate pneumoconioses, whether caused by talc, kaolin, mica or fuller's earth, show similar clinical and histopathological features. ${ }^{51}$ If lung tissue from a subject shows the features of a silicate pneumoconiosis and there is a good 
history of primary exposure to a mineral - for example, a talc miner or china clay worker then it is reasonable to make the diagnosis of talc pneumoconiosis or kaolin pneumoconiosis. However, if the occupational history is to a mixed or secondary exposure - for example, a tyre worker - then the only way to make an accurate diagnosis is to subject the lung to mineral analysis which will give a precise breakdown of the minerals present. Inaccurate diagnoses may otherwise be made - for example, talc pneumoconiosis when it might have been a mica pneumoconiosis. ${ }^{10}$

An example of how these techniques can clarify varying pathological responses within a particular group of workers comes from a study of the Cornish china clay industry. In this group of workers there were claims that exposure to quartz rather than kaolin was responsible for the pneumoconiosis. Necroscopic examination of the lungs from a series of workers from the china clay industry showed two basic histopathological patterns. One was characterised by mixed nodular and diffuse interstitial patterns of fibrosis and the other by diffuse interstitial fibrosis only. In the first group mineral analysis of the lung tissues showed significant amounts of silica as well as kaolin whereas in the second group kaolin was the predominant mineral found in the lung tissues with little or no silica. ${ }^{11}$ Careful investigation of the occupational histories revealed that the group with substantial amounts of silica had been exposed to china stone dust as well as china clay whereas the group without silica had only been exposed to china clay dust.

\section{Metals}

Although uncommon, various exposures to metals have been associated with a variety of lung diseases. ${ }^{52}$ Examples of putative associations include desquamative interstitial pneumonia with aluminium, ${ }^{53}$ giant cell interstitial pneumonia with hard metal (tungsten carbide), ${ }^{54-56}$ and granulomatous disease with beryllium. ${ }^{56}$ In some circumstances the finding of various metals within the tissue samples would be strong confirmatory evidence that they were causative of the disease - for example, beryllium in granulomas, tungsten, cobalt and/ or tantalum in cases of desquamative interstitial pneumonia or giant cell interstitial pneumonia.

In other cases such as lung cancers the interpretation would be more problematic because of confounding factors such as smoking and radon exposure. In these cases the analyses should be used to confirm the putative exposure rather than necessarily indicating causation. We have recently examined the lung tissues of three subjects with lung cancer who had been heavy smokers and who had worked in the chromate production industry for 20-25 years; the percentages of chromium particles varied from $45 \%$ to $66 \%$. These results indicated substantial exposure to chromium compounds. However, we do not have a series of exposed controls without lung cancer for comparison and therefore we do not know whether levels would necessarily be higher in the chromium induced lung cancers. Epidemiological evidence has suggested that exposures to chromate compounds were higher in the lung cancer group. ${ }^{57} \mathrm{~A}$ necroscopic study of Norwegian nickel refinery workers demonstrated higher levels of nickel and its compounds within the lung tissues of exposed workers than in nonexposed subjects, but no significant difference was seen in the exposed group between those with and without lung cancer. ${ }^{58}$

\section{Conclusion}

Mineral analysis of tissue specimens has provided very useful information in pathological conditions associated with occupational exposures to mineral particles, particularly when combined with epidemiological information. Most of the data have been related to exposures to fibrous particles such as asbestos. More investigations of this nature are required in diseases associated with exposure to non-fibrous particles. In the future it is likely that these types of investigation will be extended into the effects of pollutants.

1 Liebow AA. Foreword. In: Spencer H. Pathology of the lung. 3rd edn. Oxford: Pergamon Press, 1977.

2 Jones WR. Silicotic lungs: the minerals they contain. $f$ Hygiene 1933;33:307-29.

3 Gross P, Westrick ML, McNerny JM. Silicosis, the topographic relationship of mineral deposits to histological structures. Am f Pathol 1956;32:739-75.

4 King EJ, Belt TH. The silica content of tissues with and without silicotic lesions. $\mathcal{F}$ Pathol Bacteriol 1940;51:269-75.

5 Faulds JS, King EJ, Nagleschmidt G. Dust content of lungs of coal workers from Cumberland. Br f Ind Med 1959; 16:43-50.

6 Rivers D, Wise ME, King EJ, Nagleschmidt G. Dust content, radiology and pathology in simple pneumoconiosis of coalworkers. Br $\mathcal{F}$ Ind Med 1960;17:87-108.

7 Nagleschmidt G, Rivers D, King EJ, Trevella W. Dust and collagen content of lungs of coal workers with PMF. Brf Ind Med 1963;20:181-91.

8 Hale LW, Gough J, King EJ, Nagleschmidt G. Pneumoconiosis of kaolin workers. Br $\mathcal{F}$ Ind Med 1956;13:251-9.

9 Pooley FD. Tissue mineral identification. In: Weill $\mathrm{H}$, Turner-Warwick M, eds. Occupational lung diseases. Research approaches and methods. New York: Marcel Decker, search approaches ar $1981: 189-235$.

10 Gibbs AR, Pooley FD, Griffiths DM, Mitha R, Craighead JE, Ruttner JR. Talc pneumoconiosis: a pathologic and mineralogic study. Hum Pathol 1992;23:1344-54.

11 Wagner JC, Pooley FD, Gibbs AR, Lyons J, Sheers G, Moncrieff CB. Inhalation of china stone and china clay dusts: relationship between the mineralogy of the dust retained in the lungs and pathological changes. Thorax 1986;41:190-6.

12 Gibbs A, Craighead JE, Pooley FD, Wagner JC. The pathology of slate workers' pneumoconiosis in North Wales and Vermont. Ann Occup Hyg 1988;32:273-8.

13 Gibbs AR, Stephens M, Griffiths DM, Blight BJN, Pooley FD. Fibre distribution in the lungs and pleura of subjects with asbestos related diffuse pleural fibrosis. $B r f$ Ind $M e d$ 1991;48:762-70.

14 Churg A, Wiggs B, DePaoli L, Kampe B, Stephens B. Lung asbestos content in chrysotile workers with mesothelioma. Am Rev Respir Dis 1984;130:1042-5.

15 Wagner JC, Pooley FD, Berry G, Seal RME, Munday DE, Morgan J. A pathological and mineralogical study of asbestos-related deaths in the United Kingdom in 1977. ann Occup Hyg 1982;26:423-31.

16 Wagner JC, Newhouse ML, Corrin B, Rossiter CE, Griffiths DM. Correlation between lung fibre content and disease in East London asbestos factory workers. $\mathrm{Br} \mathcal{F}$ Ind $\mathrm{Med}$ 1988;45:305-8.

17 Jones JSP, Pooley FD, Clark NJ, Owen WG, Roberts GH, Smith PG. The pathology and mineral content of lungs in cases of mesothelioma in the United Kingdom in 1976. IARC Scientific Publications 1980;30:187-99.

18 Gibbs AR, Gardner MJ, Pooley FD, Griffiths DM, Blight B, Wagner JC. Fibre levels and disease in workers from a factory predominantly using amosite. Environ Health a factory predominantly using amosi
Perspect 1994;102 (Suppl 5):261-3.

19 Sebastien P, Fondimare A, Bignon J, Monchaux G, Desbordes J, Bonnaud G. Topographic distribution of asbestos fibres in human lung in relation to occupational and nonfibres in human lung in relation to occupational and non-
occupational exposure. In: Walton WH, McGovern B, occupational exposure. In: Walton WH, McGovern B,
eds. Inhaled particles IV. New York: Pergamon Press, 1977: 435-44. 
20 Morgan A, Holmes A. The distribution and characteristics of asbestos fibres in the lungs of Finnish anthophyllite asbestos workers. $B r$ f Ind Med 1984;33:62-75.

21 Churg A. The distribution of amosite asbestos in the periphery of the normal human lung. Br 7 Ind Med 1990;47: 677-81.

22 Churg A, Wood P. Observations on the distribution of asbestos fibres in human lungs. Environ Res 1983;31: 374-80.

23 Bergman I. Determination of coal in formalin-fixed pneumoconiotic lungs. Anal Chem 1966;38:441-4.

24 Gold C. The quantitation of asbestos in tissue. 7 Clin Pathol 1968;21:537a.

25 Gross P, Tuma J, De Treville RTD. Fibrous dust particles and ferruginous bodies. Arch Environ Health 1970;21: 38-46.

26 Smith MJ, Naylor B. A method for extracting ferruginous bodies from sputum and pulmonary tissue. Am $₹$ Clin Pathol 1972;68:250-4.

27 Nenadic CM, Crable IV. Enzymatic digestion of human lung tissue. Am Ind Hyg Assoc 7 1970;31:81-6.

28 Jaunarajs KL, Leibling RS. The digestion of lung tissue for mineral dust recovery. Am Ind Hyg Assoc $\mathcal{F}$ 1972;33: 535-42.

29 Lee RJ, Lally JS, Fisher RM. Identification and counting of mineral fragments. National Bureau of Standar

30 Lee RJ, Florida RG, Stewart IM. Asbestos contamination in paraffin tissue blocks. Arch Pathol Lab Med 1995;119: 528-32.

31 Gibbs AR, Pooley FD. Toxicology elsewhere. Bits and pieces: asbestos contamination in paraffin tissue blocks. Hum Exp Toxicol 1996;15:85-6.

32 Ashcroft T, Heppleston AG. The optical and electron microscopic determination of pulmonary asbestos fibre concentration and its relation to the human pathological reaction. $f$ Clin Pathol 1973;26:224-43.

33 Dodson RF, O'Sullivan M, Corn CJ, Garcia JGN, Stocks $\mathrm{JM}$, Griffith DE. Analysis of ferruginous bodies in bronchoalveolar lavage from foundry workers. $\mathrm{Br} \mathcal{F}$ Ind Med 1993;50:1032-8.

34 Crouch E, Churg A. Ferruginous bodies and the histologic evaluation of dust exposure. Am F Surg Pathol 1984;8: 109-16.

35 Roggli V. Asbestos bodies and nonasbestos ferruginous bodies. In: Roggli VL, Greenberg SD, Pratt PC, eds. Pathology of asbestos-associated diseases. Boston: Little Brown, 1992. 39-75.

36 Pooley FD, Ranson DL. Comparison of the results of asbestos fibre counts in lung tissue obtained by analytical electron microscopy and light microscopy. $f$ Clin Pathol 1986;39:313-7.

37 Churg A. Mineralogic correlates of fibrosis in chrysotile miners and millers. Am Rev Respir Dis 1989;139:891-6.

38 Churg A. Fibre counting and analysis in the diagnosis of asbestos-related disease. Hum Pathol 1982;13:381-92.

39 Baker DB. Limitations in drawing etiologic inferences based on measurement of asbestos fibres from lung tissue. Ann NY Acad Sci 1991;643:61-70.

40 Churg A. Analysis of asbestos fibres from lung tissue: research and diagnostic uses. Sem Respir Med 1986;7:281-8.

41 Kohyama N. Airborne asbestos levels in non-occupational environments in Japan. In: Bignon J, Peto J, Saracci $\mathrm{R}$, eds. Non-occupational exposure to mineral fibres. Lyon International Agency for Research in Cancer, 1989: 26276.
42 Roggli V. Human disease consequences of fibre exposures: review of human lung pathology and fibre burden data. Environ Health Perspect 1990;88:295-303.

43 Whitwell F, Scott J, Grimshaw M. Relationship between occupations and asbestos fibre content of the lungs in patients with pleural mesothelioma, lung cancer and other diseases. Thorax 1977;32:377-86.

44 Wagner JC, Moncrieff CB, Coles R, Griffiths DM, Munday DE. Correlation between the fibre content of the lungs and disease in naval dockyard workers. $\mathrm{Br}$ f Ind Med 1986; 43:391-5.

45 Stephens $\dot{M}$, Gibbs AR, Pooley FD, Wagner JC. Asbestos induced pleural fibrosis: pathology and mineralogy. Thorax induced pleural

46 Gibbs AR, Jones JSP, Pooley FD, Griffiths DM, Wagner JC. Non-occupational malignant mesotheliomas. In: Bignon J, Peto J, Saraci R eds. Non-occupational exposure to mineral fibres. Lyon: IARC Scientific Publications 1989;90:21928.

47 Wagner JC, Berry G, Pooley FD. Mesotheliomas and asbestos type in asbestos textile workers: a study of lung contents. BMF 1982;285:603-6.

48 Teschler H, Konietzko N, Schoenfeld B, Ramin C, Schraps $T$, Costabel U. Distribution of asbestos bodies in the human lung as determined by bronchoalveolar lavage. Am Rev Respir Dis 1993;147:1211-5.

49 De Vuyst P, Dumortier P, Moulin E, Yourassoxsky N, Ruyst $\mathrm{P}$, Dumortier $\mathrm{P}$, Moulin E, Yourassoxsky $\mathrm{N}$, Roomans $\mathrm{P}$, DeFranquen $\mathrm{P}$, et al. Diagnostic value of asbestos bodies in

50 Pairon JC, Orlowski E, Iwatsubo Y, Billon-Galland MA, Dufour G, Chammings S, et al. Pleural mesothelioma and exposure to asbestos; evaluation from work histories and analysis of asbestos bodies in bronchoalveolar lavage fluid or lung tissue in 131 patients. Occup Environ Med 1994; 51:244-9.

51 Craighead JE, Kleinerman J, Abraham JL, Gibbs AR, Green FHY, Harley RA et al. Diseases associated with exposure to silica and non-fibrous silicate minerals. Arch Pathol Lab Med 1988;112:673-720.

52 Nemery B. Metal toxicity of the respiratory tract. Eur Respir $71990 ; 3: 202-19$

53 Herbert A, Sterling E, Abraham JL, Corrin B. Desquamative interstitial pneumonia in an aluminium welder. Hum Pathol 1982;13:694-9.

54 A pram J exposure using open biopsy, transbronchial biopsy and exposure using open biopsy, transbronchial biopsy and brochopulmonary lavage in giant cell interstitial pneu-

55 monia (GIP). Am Rev Respir Dis 1979;119(Suppl).196. Davison AG, Haslam PL, Corrin B, Coutts II, Dewar A, Riding WD, et al. Interstitial lung disease and asthma in hard metal workers: bronchoalveolar lavage, ultrastructural and analytical findings and result provocation tests. Thorax 1983;38:119-28.

56 Jones Williams W. Beryllium disease. In: Parkes WR, ed. Occupational lung disease. 3rd edition. Oxford: Butterworth Heinemann, 1994:571-92.

57 Davies JM, Easton DF, Bidstrup PL. Mortality from respiratory cancer and other causes in United Kingdom pirromate production workers. Br F Ind Med 1991;48. 299-313.

58 Andersen I, Svenes KB. Determination of nickel in lung specimens of thirty nine autopsied nickel workers. Int Arch specimens of thirty nine autopsied

59 Dawson A, Gibbs AR, Pooley FD, Griffiths DM, Hoy J. Malignant mesothelioma in women. Thorax 1993;48: J. Malign

60 Gibbs AR, Pooley FD, Griffiths DM. Lung fibrous conten of subjects with pleural plaques. Eur Respir f 1994;7(Suppl 18):425s. 